\title{
Habitat Utilization and Feeding Biology of Himalayan Grey Langur (Semnopithecus entellus ajex) in Machiara National Park, Azad Jammu and Kashmir, Pakistan
}

\author{
Riaz Aziz Minhas ${ }^{1, *}$, Khawaja Basharat Ahmed ${ }^{2}$, Muhammad Siddique Awan², Naeem Iftikhar Dar ${ }^{3}$ \\ (1. World Wide Fund for Nature-Pakistan (WWF-Pakistan) AJK Office Muzaffarabad, Azad Jammu and Kashmir 13100, Pakistan; \\ 2. Department ofZoology, University of Azad Jammu and Kashmir Muzaffarabad, Azad Jammu and Kashmir 13100, Pakistan; \\ 3. Department of Wildlife and Fisheries, Government of Azad Jammu and Kashmir, Muzaffarabad, Azad Jammu and Kashmir 13100, Pakistan)
}

\begin{abstract}
Habitat utilization and feeding biology of Himalayan Grey Langur (Semnopithecus entellus ajex) were studied from April, 2006 to April, 2007 in Machiara National Park, Azad Jammu and Kashmir, Pakistan. The results showed that in the winter season the most preferred habitat of the langurs was the moist temperate coniferous forests interspersed with deciduous trees, while in the summer season they preferred to migrate into the subalpine scrub forests at higher altitudes. Langurs were folivorous in feeding habit, recorded as consuming more than 49 plant species (27 in summer and 22 in winter) in the study area. The mature leaves (36.12\%) were preferred over the young leaves $(27.27 \%)$ while other food components comprised of fruits $(17.00 \%)$, roots $(9.45 \%)$, barks $(6.69 \%)$, flowers $(2.19 \%)$ and stems $(1.28 \%)$ of various plant species.
\end{abstract}

Key words: Himalayan Grey Langur; Habitat; Food biology; Machiara National Park

\section{喜马拉雅灰叶猴栖息地利用和食性生物学}

\author{
Riaz Aziz Minhas ${ }^{1, *}$, Khawaja Basharat Ahmed ${ }^{2}$, Muhammad Siddique Awan ${ }^{2}$, Naeem Iftikhar Dar ${ }^{3}$ \\ (1. World Wide Fund for Nature-Pakistan (WWF-Pakistan) AJK Office Muzaffarabad, Azad Jammu and Kashmir 13100, Pakistan; \\ 2. Department of Zoology, University of Azad Jammu and Kashmir Muzaffarabad, Azad Jammu and Kashmir 13100, Pakistan; \\ 3. Department of Wildlife and Fisheries, Government of Azad Jammu and Kashmir, Muzaffarabad, Azad Kashmir 13100, Pakistan)
}

摘要: 2006 年 4 月至 2007 年 4 月在巴基斯坦克什米尔地区马希亚拉国家公园（Machiara National Park）对喜 马拉雅灰叶猴(Semnopithecus entellus ajex)的栖息地利用和食性生物学进行研究。结果表明, 冬天, 叶猴首选的栖 息地多为温暖湿润的针叶林和落叶林混交地区; 夏天, 它们则迁移至高海拔的亚高山灌木丛林里。喜马拉雅灰叶 猴主要以植物的叶子为食, 研究期间在该地区共发现 49 种被采食过的植物（夏季 27 种, 冬季 22 种)。通过观察 它们的所有食物, 发现老叶(36.12\%)比嫩叶(27.27\%)更受欢迎，随后依次为果实 $17.00 \%$ 、树根 9.45\%、树皮 6.69\%、 花 $2.19 \%$ 和根茎 $1.28 \%$ 。

关键词: 喜马拉雅灰叶猴; 栖息地; 食性生物学; 马希亚拉国家公园

中图分类号: Q959.848; Q958.122.5; Q959.848.08 文献标志码: A 文章编号: 0254-5853-(2010)02-0177-012

The Grey Langur or Hanuman Langur (Semnopithecus entellus) is large-sized and most widely distributed animal species of the 19 non-human primate species, found in the Indian subcontinent (Roonwal \& Mohnot, 1977). Himalayan Grey Langur (S. entellus ajax) belongs to the family Cercopithecidae and subfamily Colobinae, which includes all the old-world monkeys with folivorous feeding habit (Roberts, 1997; Thorington \& Anderson, 1984).
Himalayan Grey Langur is found in Himachal Paradesh, India (Great Himalayan National Park, Kallatop-Khajjiar and Manali Wildlife sanctuaries) and State of Jammu Kashmir (Kishtwar National Park), Nepal (Lang Tang National Park of Central Province) (Walker \& Molur, 2004). In Pakistan, these langurs are confined to Azad Jammu and Kashmir and District Mansehra, Pallas Kohistan, Bankad Dubair and Pattan (Roberts, 1997). In Azad Jammu and Kashmir, these

Received date: 2009-08-10; Accepted date: 2010-02-23

${ }^{*}$ Corresponding author (通讯作者), Cell: 92-03015370744, E-mail: riazminhas79@yahoo.com

收稿日期：2009-08-10；接受日期：2010-02-23 
beautiful monkeys are distributed in Neelum Valley (Machiara National Park and Salkhala Game Reserve), Jehlum Valley (Moji Game Reserve and surroundings), and Hillan and Phalla game reserves in District Bagh (Ahmed, 1999; Baig, 2004; Dar, 2006) (Fig. 1).

The Langurs are ecologically very adoptable to a

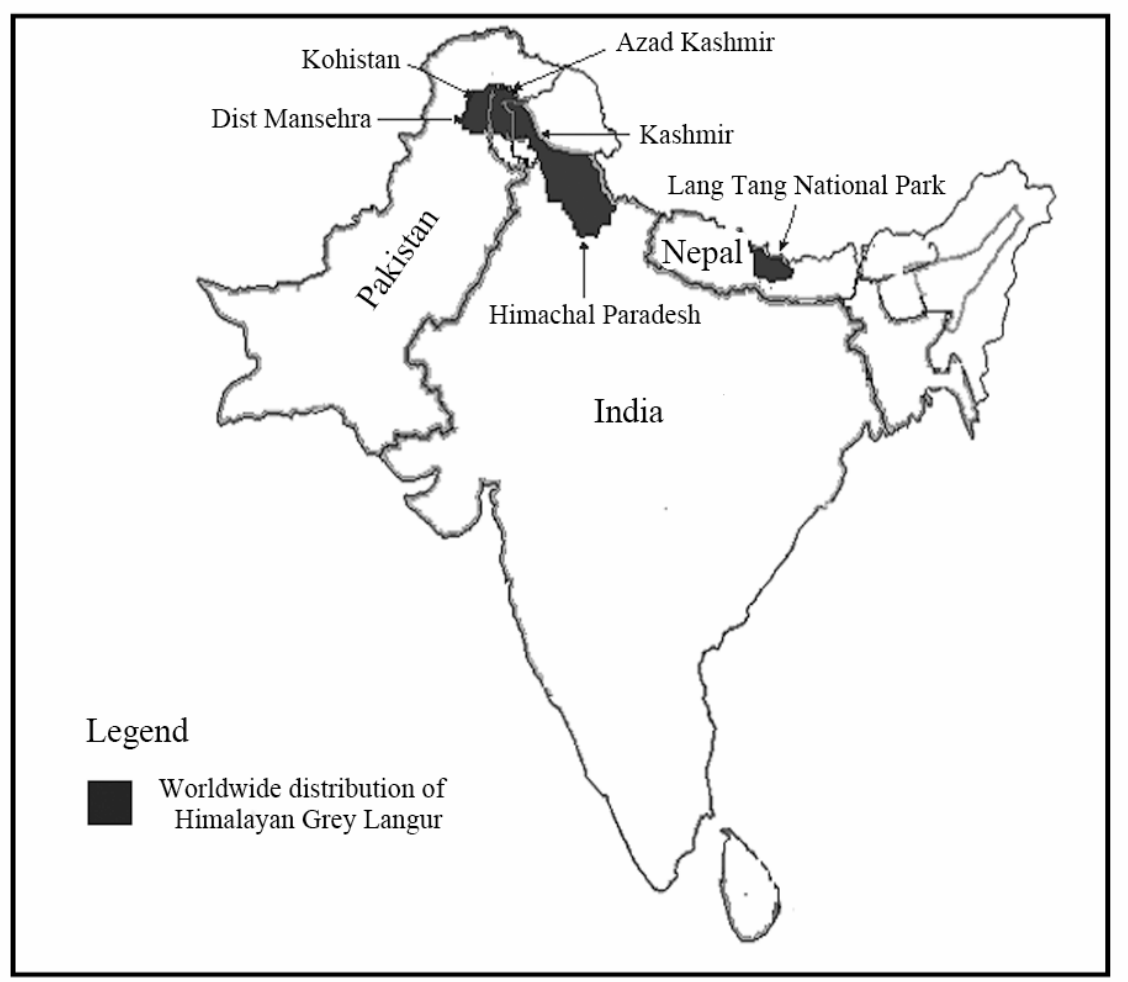

Fig. 1 Worldwide distribution of Himalayan Grey Langurs (Semnopithecus entellus ajax)

variety of habitats, including quite dry savannah and tropical rain forests. They inhabit between $2200-4000$ $\mathrm{m}$ asl (above sea level) in the subtropical, tropical moist temperate, alpine, coniferous, broadleaved forests and scrublands (Nowak, 1999; Hilton \& Taylor, 2000; Roberts, 1997). They are arboreal and diurnal species and prefer to jump from tree to tree through the branches when foraging but some may become accustomed to living close to the human settlements (Tritsch, 2001).

The Himalayan Langurs are mainly folivorous species, but also consume fruits, flowers, cultivated crops, seeds with high levels of the toxins, like, strychnine (Strychnos non-vomica) and distasteful vegetation avoided by other creatures. The animal is exclusively herbivorous, feeding mainly on young leaf buds, shoots and other vegetations (Roberts, 1997), but observations in the open scrub forests of Jodhpur reveal that the insects may also constitute a regular part of their diet and that insectivory is particularly prevalent in the monsoon months of July-September (Srivastava, 1991). Moore (1985) in a study of langur all-male bands also observed five episodes of active insect predation.
All the primate taxa including langurs in the South Asia are under severe threats. The major and common threats through out the region are the habitat loss and degradation through human encroachment, overgrazing, building roads through forests, lopping, deforestation, agriculture, fire, unavailability of food, predation by carnivores (leopards and tigers) and attack of several viral and bacterial diseases. Present and future threats are mainly due to agriculture and development practices (Biswas \& Sankar, 2002; Bagchi et al, 2003; Nandi et al, 2003; Nowak, 1999). The species does not raid the crops, therefore, it does not invite the anger of local villagers but the living conditions for such a leaf eating species are very harsh in the long winter season at these altitudes (Roberts, 1997).

Although habitat of these langurs is stable in the area, but is predicted future decline by $10 \%$ during the next 10 years due to forest clearance for agriculture and encroachments. There has already been a decrease in habitat quality due to such alterations (Hilton \& Taylor, 2000).

Langurs are endangered because of an encroaching 
human expansion (Nowak, 1999). The International Union for the Conservation of Nature and Natural Resources (IUCN) in 2000 classified the 'Semnopithecus entellus ajax' as Lower Risk; near threatened and now due to improved information and taxonomic revision [CRB1ab(iii,v) +2 ab (iii,v) ver.3.1 (2001)], this subspecies was reassessed in 2004 and is now regarded as “Critically Endangered” (IUCN, 2006). According to Roberts (1997), this monkey was very rare in Pakistan, and excluding Azad Jammu and Kashmir, its total population was estimated to be less than 200 individuals. In Azad Jammu and Kashmir however, its population is better as compare to Pakistan and according to an estimate there are more than 500 individuals in Azad Jammu and Kashmir (Dar, 2006).

Above-mentioned facts reveal that the animal is highly important with the conservation point of view as its population is restricted to a very small area and is continuously declining throughout the range. Moreover, the habitat conditions and availability of food for this species were never studied and remain unclear throughout its distribution range in Pakistan and Azad Jammu and Kashmir. Therefore, a proper study of this critically endangered species with special reference to the assessment of the existing habitat and available food for this species in Machiara National Park Azad Jammu and Kashmir was highly demanded. The present study is a step to address these issues for future management and conservation of this species.

\section{Materials and Methods}

\subsection{Study area}

Machiara National Park (MNP) lies at $34^{\circ} 31^{\prime} \mathrm{N}$ latitude and $73^{\circ} 37^{\prime} \mathrm{E}$ longitude, covering an area of about $135.35 \mathrm{~km}^{2}$ (33 450 acres), and between $2000 \mathrm{~m}$ to $4733 \mathrm{~m}$ above the sea level. The Park is located at a distance of about $35 \mathrm{~km}$ from Muzaffarabad (the capital city of Azad State of Jammu and Kashmir, Pakistan). On its northern side it is bounded by Neelum Valley while the Kaghan Valley (North West Fronteir Province, Pakistan) surrounds it from the western side. Along the Southern periphery of the Machiara National Park, there are 30 villages comprising 7635 households and 52792 persons (Fig. 2). The region is influenced by the southwest monsoon. The average annual temperature ranges between $13{ }^{\circ} \mathrm{C}$ and $27^{\circ} \mathrm{C}$ with the extremity between -2 to 46 . Generally the spring (February to April) and monsoon (July to August) are the raining seasons of the year.
MNP is a true representative of Himalayan Mixed Forest-Rangeland Ecosystem. It comprises of Himalayan moist temperate forests, Himalayan dry coniferous forests, subalpine scrub forest and alpine pastures. The park is very rich in biodiversity and provides habitat to hundreds of important animals, birds and plant species, including rare and globally significant wildlife species of Snow leopard (Uncia uncia), Musk deer (Moschus chrysogaster), Western Horned-tragopon (Tragopan melanocephalus), Cheer pheasant (Catreus wallichii), Lammergeier (Gypaetus barbatus) and the Himalayan Griffon vulture (Gyps himalayensis). Trees such as fir (Abies pindrow), spruce (Picea smithiana), deodar (Cedrus deodara), blue pine (Pinus wallichiana) and barmi (Taxus wallichiana) dominate the floral cover. Among the broad-leaved species, Bankhor (Aesculus indica) and Kalakat (Prunus cornutus) are important. Barmi (Taxus wallichiana), a globally threatened species, occurs in good number in MNP and is therefore, protected under CITES (Beig, 2004; Hassan, 2004).

\subsection{Methods}

Three "focal groups" of the langurs were selected and assigned names. These focal groups included two bisexual troops \{one uni-male bisexual (UMBS) and one multimale bisexual (MMBS) $\}$ and one all-male band (AMB).

For the assessment of habitat, vegetation type including grasses (annual or perennial herbaceous plants with hollow and jointed stems), herbs (annual or perennial angiospermic plants with small and soft stems), shrubs (woody plants with many stems rising from the ground and trees (with single woody stem), topography and dominant plant species were recorded. Data on feeding behaviour were collected using focal and scan sampling techniques in which the activities of visible animals were recorded throughout the day from dawn to dusk following Altman (1974) and Chhangani \& Mohnot (2004). Data were collected for 72 hours per month for each of the focal troops (UMBS, MMBS and AMB) for three consecutive days in a month. One day prior to the commencement of data collection, the trees on which the focal group roosted were located. This strategy facilitated to start observation next day before the group would leave its sleeping trees early in the morning. While scaning the feeding activities of the animals, the record of plant species and plant part eaten was noted. Unidentifiable plant samples were collected and labeled for afterward identification. Much of the information was obtained by the examination of the signs they left behind. 
These include partially eaten flowers, fruits, roots and leaves. For this purpose identified animals were followed from dawn to dusk, and types and numbers of food items brought into the mouth were recorded for each minute of observation. To supplement the field data, a number of knowledgeable local people were also interviewed.
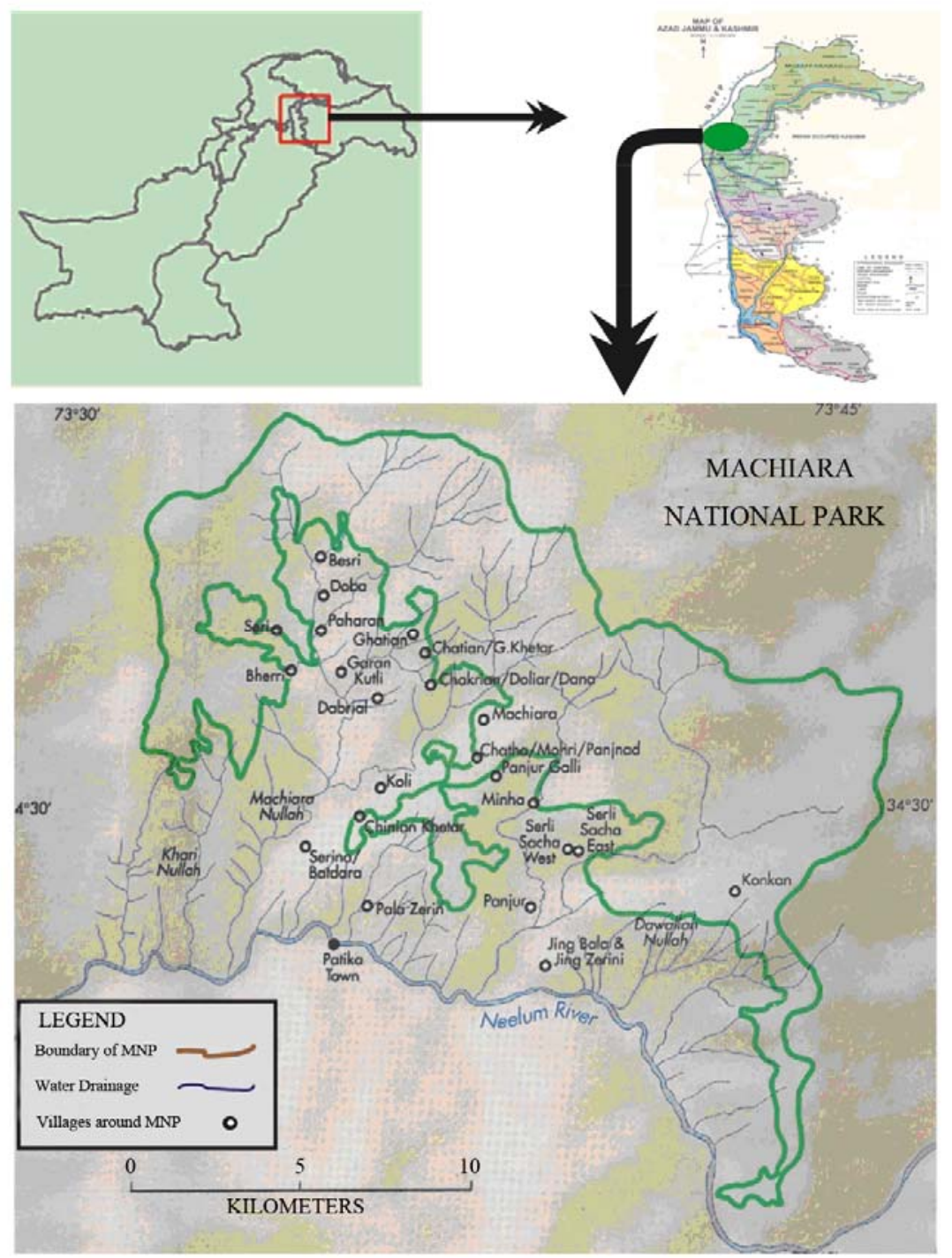

Fig. 2 Location map of the study area (Machiara National Park)

\section{Results}

\subsection{Habitat utilization}

In Machiara National Park langurs were usually found in the moist temperate coniferous habitats with mixed deciduous forests. However during the summer season they migrated upwards into the subalpine scrub forests and in some localities even further into the alpine zone (Ganja Mountains). In most of the habitats, they preferred moist temperate forests with dominant deciduous vegetations. They have never been observed penetrating into the cultivated areas in or around the villages, however they were observed many times in the cultivated fields inside the forest areas during the winter. It was also observed that the langurs sometimes overlapped the habitats of rhesus monkeys during the winter months and they were never observed together in the summer since during these months the rhesus monkeys were usually found in the vicinity of the cultivated areas while the langurs were found penetrating into the high altitudinal areas mostly overlapping the habitats of musk deer in subalpine scrub forests. Most of the langur troops were found in the areas where adequate water was available. The habitat preferences of the three focal groups of langurs with the dominant vegetations and seasonal variations are given below. 
UMBS troop was found around Kole DaberSilade-Purana Chhanj-Thora (Forest Compartment No. 9a) localities on the South-Western aspect, the hilly area with about $60 \%$ slop. During the winter season this troop was mostly confined to the moist temperate coniferous forests mixed with deciduous trees, dominated with Quercus incana, Vibernum nervosum and Achillea millefolium at about $2250-2700 \mathrm{~m}$ above sea level (asl) (Tab. 1, Tab. 2). However, during the summer months this troop penetrated into the subalpine scrub forests dominated by Juniperus communis and Salix denticulate up to $3800 \mathrm{~m}$ asl. The area was disturbed during the summer season by the livestock and human population and usually remained undisturbed in winter. The other important animals found in the area were black bear, leopards, martens, musk deer, gorals, tragopans, monals and koklass (Tab. 1).

The second focal troop MMBS was confined to Domailan, Reveri and Kuthial (Forest Compartment No. 9b) areas situating on the South-Western aspect of the Ganja Mountain ranges with more than $60 \%$ slop. The troop remained confined to the moist temperate coniferous forests mixed with deciduous trees dominated with Aesculus indica in the western aspect while with Quercus incana on the southern and northern aspects at about $2000-2500 \mathrm{~m}$ asl. Among the shrubs and herbs,
Indigofera heterantha, Vibernum nervosum and Valeriana jatamansi were the dominant species of langur's habitat (Tab. 1). Like the UMBS, this troop also moved upwards into the subalpine scrub forests dominated by Juniperus communis, Salix flabellaris and Salix denticulate in the summer months. Water sources were sufficiently available throughout the area. The disturbance remained during the most part of the year, reaching at the peak in the summer when livestock grazing and human settlements were at maximum (Tab. 1). The dominant plant species (Tab. 3) and the important animals in the area were black bear, leopards, musk deer, yellow throated martens, gorals, tragopans, monals, chukors and koklass.

The third focal group was an all-male band nominated as AMB found in Jhugian-Danna Magri (Forest Compartment No.15 a \& b) localities between $1790-3000 \mathrm{~m}$ asl. The area comprised of high cliffs of more than $60 \%$ slops. The band remained confined in the moist and dry temperate coniferous forests mixed with deciduous trees. Pinus wallichiana was the dominant tree species in the area while among the shrubs and herbs Phytolacca letbenia and Viola odorata were recorded as the dominant species (Tab. 4). The area was disturbed during the summer season by the livestock grazing, human settlements and agricultural activities, which

Tab. 1 Habitat utilization by focal langur troops and all male bands in Machiara National Park during 2006-2007

\begin{tabular}{|c|c|c|c|c|c|c|c|c|c|c|}
\hline \multirow[b]{2}{*}{ Sr. \# } & \multirow{2}{*}{$\begin{array}{l}\text { Name } \\
\text { of troop } \\
\text { / band }\end{array}$} & \multirow[b]{2}{*}{$\begin{array}{l}\text { Name of } \\
\text { locality }\end{array}$} & \multirow[b]{2}{*}{ Aspect } & \multirow[b]{2}{*}{$\begin{array}{l}\text { Slop } \\
(\%)\end{array}$} & \multirow[b]{2}{*}{ Habitat type } & \multirow[b]{2}{*}{ Land use } & \multicolumn{3}{|c|}{ Dominant vegetations } & \multirow[b]{2}{*}{$\begin{array}{l}\text { Associated } \\
\text { animals }\end{array}$} \\
\hline & & & & & & & $\begin{array}{l}\text { Dominant } \\
\text { trees }\end{array}$ & $\begin{array}{c}\text { Dominant } \\
\text { shrubs }\end{array}$ & $\begin{array}{c}\text { Dominant } \\
\text { herbs }\end{array}$ & \\
\hline 1 & UMBS & $\begin{array}{l}\text { Sila } \\
\text { Da-Prana } \\
\text { Chanj- } \\
\text { Thora }\end{array}$ & SW & 60 & $\begin{array}{l}\text { Moist temp. } \\
\text { mixed } \\
\text { coniferous } \\
\text { forests, } \\
\text { subalpine } \\
\text { scrubs }\end{array}$ & $\begin{array}{l}\text { Pasture, } \\
\text { forests }\end{array}$ & $\begin{array}{l}\text { Quercus } \\
\text { incana }\end{array}$ & $\begin{array}{l}\text { Vibernum } \\
\text { nervosum }\end{array}$ & $\begin{array}{l}\text { Achillea } \\
\text { millefoli- } \\
\text { um }\end{array}$ & $\begin{array}{l}\text { Black bear, } \\
\text { leopard, } \\
\text { tragopan, } \\
\text { koklass, } \\
\text { monal, } \\
\text { monkeys } \\
\text { musk deer }\end{array}$ \\
\hline 2 & MMBS & $\begin{array}{l}\text { Thora- } \\
\text { Khuthiali- } \\
\text { Domallan }\end{array}$ & NW & 60 & $\begin{array}{l}\text { Moist temp. } \\
\text { mixed } \\
\text { coniferous } \\
\text { forest, } \\
\text { subalpine } \\
\text { scrubs }\end{array}$ & $\begin{array}{l}\text { Pasture, } \\
\text { forests }\end{array}$ & $\begin{array}{l}\text { Aesculus } \\
\text { indica }\end{array}$ & $\begin{array}{l}\text { Indigofera } \\
\text { heterantha }\end{array}$ & $\begin{array}{l}\text { Valeriana } \\
\text { jatamansi }\end{array}$ & $\begin{array}{l}\text { Black bear, } \\
\text { leopard, goral, } \\
\text { tragopan, } \\
\text { koklass, } \\
\text { monal, } \\
\text { monkeys, } \\
\text { musk deer }\end{array}$ \\
\hline 3 & AMB & $\begin{array}{l}\text { Jhugian- } \\
\text { Danna } \\
\text { magri }\end{array}$ & $\mathrm{NE}$ & 70 & $\begin{array}{l}\text { Moist and } \\
\text { dry temp- } \\
\text { erate mixed } \\
\text { forests }\end{array}$ & $\begin{array}{l}\text { Agricultu } \\
\text { ral lands, } \\
\text { forests }\end{array}$ & $\begin{array}{l}\text { Pinus } \\
\text { wallichi- } \\
\text { ana }\end{array}$ & $\begin{array}{l}\text { Phytolacca } \\
\text { letbenia }\end{array}$ & $\begin{array}{l}\text { Viola } \\
\text { odorata }\end{array}$ & $\begin{array}{l}\text { Black bear, } \\
\text { leopard, } \\
\text { koklass, } \\
\text { monal, } \\
\text { monkeys }\end{array}$ \\
\hline
\end{tabular}

UMBS: uni-male bisexual troop, MMBS: multi-male bisexual troop, AMB: all-male band. NE: North East, NW: North West, SW: South West. 
Tab. 2 List of important vegetation found in the habitat of troop UMBS

\begin{tabular}{|c|c|c|}
\hline Trees & Shrubs & Herbs \\
\hline Quercus incana & Jasminum humile & Adiantum incisum \\
\hline Abies pindrow & Plectranthus rugosus & Androsace rotundifolia \\
\hline Aesculus indica & Rubus ulmifolium & Valeriana jatamansii \\
\hline Betula utilis & Viscum album & Potentilla gerardiana \\
\hline Picea smithiana & Sorbaria tomentosa & Rheum emodi \\
\hline Juglans regia & Rubus ellipticus & Mentha longifolia \\
\hline Pinus wallichiana & Vibernum foetens & Iris hookeriana \\
\hline Prunnus cornuta & Vibernum nervosum & Роа аппиа \\
\hline Taxus wallichiana & Indigofera heterantha & Podophyllum emodi \\
\hline Celtis australis & Salix denticulata & Thlapsi arvensis \\
\hline \multirow[t]{17}{*}{ Grewia tenax } & Salix flabellaris & Polygonum amplexicaulis \\
\hline & Rhodendron hypenanthum & Geranium nepalens \\
\hline & Juniperus communis & Thymus serpyllum \\
\hline & Indigofera linifolia & Plantago lanceolata \\
\hline & Vitis vinifera & Cymbopogan matini \\
\hline & Berbris aristidae & Solanum nigrum \\
\hline & Berbris lycium & Podophyllum emodi \\
\hline & & Dryopteris stewartii \\
\hline & & Dryopteris ramose \\
\hline & & Skimmia laureola \\
\hline & & Malva spp. \\
\hline & & Asphodelus tenuifolius \\
\hline & & Geranium wallichianum \\
\hline & & Ziziphus jujube \\
\hline & & Solanum tuberosum \\
\hline & & Urtica dioica \\
\hline & & Achillea millefolium \\
\hline
\end{tabular}

Tab. 3 List of important vegetation found in the habitat of troop MMBS

\begin{tabular}{|c|c|c|}
\hline Trees & Shrubs & Herbs \\
\hline Quercus incana & Jasminum humile & Adiantum incisum \\
\hline Abies pindrow & Plectranthus rugosus & Androsace rotundifolia \\
\hline Aesculus indica & Rubus ulmifolium & Valeriana jatamansii \\
\hline Betula utilis & Viscum album & Potentilla gerardiana \\
\hline Picea smithiana & Sorbaria tomentosa & Rheum emodi \\
\hline Juglans regia & Rubus ellipticus & Mentha longifolia \\
\hline Pinus wallichiana & Vibernum foetens & Iris hookeriana \\
\hline Prunnus cornuta & Vibernum nervosum & Роа аппиа \\
\hline Taxus wallichiana & Indigofera heterantha & Podophyllum emodi \\
\hline Celtis australis & Salix denticulata & Thlapsi arvensis \\
\hline Grewia tenax & Salix flabellaris & Polygonum amplexicaulis \\
\hline \multirow[t]{21}{*}{ Diospyros lotus } & Rhodendron hypenanthum & Geranium nepalens \\
\hline & Juniperus communis & Thymus serpyllum \\
\hline & Deutzia staminea & Cymbopogan matini \\
\hline & Parratiopsis jacquementiana & Fragaria nubicola \\
\hline & Ribes alpestre & Plantago major \\
\hline & Elaeagnus spp. & Impatiens edgeworthii \\
\hline & Rosa burnonii & Euphorbia spp. \\
\hline & Jurinea dolomiaea & Datura stramonium \\
\hline & Indigofera linifolia & Solanum nigrum \\
\hline & Ziziphus mauritiana & Dryopteris stewartii \\
\hline & Skimmia laureola & Dryopteris ramose \\
\hline & Rosa moschata & Lavatera spp. \\
\hline & Ziziphus nummularia & Podophyllum emodi \\
\hline & Ziziphus mauritiana & Bistorta spp. \\
\hline & Ziziphus jujube & Polygonum alpinum \\
\hline & & Malva spp \\
\hline & & Asphodelus tenuifolius \\
\hline & & Cymbopogan martini \\
\hline & & Geranium wallichianum \\
\hline & & Phaseolus aconitifolius \\
\hline & & Solanum tuberosum \\
\hline
\end{tabular}


resulted temporarily in the seasonal movements of the band (Tab. 1). The important animals found in the area were black bear, leopards, martens, monals and koklass.

\subsection{Sleeping sites}

During the study of the home ranges and habitats of the focal troops and the all-male band, the sleeping sites and tree species used for the roosting were also observed in each habitat. At the end of the day all the individuals would gather around the sleeping sites and on the onset of darkness they would climb up the trees for the sleeping purpose. All focal groups used 2-11 large and small trees of various species for the roosting within their home ranges (Tab. 5).

The study troop (UMBS) mostly used eight sleeping sites, where in they mostly roosted on the 3-7 trees of Betula utilis and Quercus incana in three sites during the summer season while Aesculus indica, Abies pindrow and Juglans regia were used at the five roosting sites

Tab. 4 List of important vegetation found in the habitat of troop AMB

\begin{tabular}{lll}
\hline Trees & Shrubs & Herbs \\
\hline Pinus wallichiana & Strobilanthus urticifolius & Adiantum incisum \\
Abies pindrow & Plectranthus rugosus & Androsace rotundifolia \\
Aesculus indica & Rubus ulmifolium & Potentilla gerardiana \\
Juglans regia & Viscum album & Cotoneaster affinis \\
Picea smithiana & Sorbaria tomentosa & Mentha longifolia \\
Prunnus cornuta & Sambocus wightiana & Poa annua \\
Celtis australis & Phytolacca latbenia & Trifolium repens \\
Cedres deodara & Vibernum nervosum & Arisaema jacquemontii \\
Diospyros lotus & Indigofera heterantha & Polygonum amplexicaulis \\
& Desmodium elegans & Geranium nepalens \\
& Phytolacca letbenia & Onychium contiguum \\
& & Plantago major \\
& & Dryopteris stewartii \\
& & Cymbopogan matini \\
\hline
\end{tabular}

Tab. 5 Sleeping Sites and Tree species used by the focal troops of langurs during 2006-2007

\begin{tabular}{|c|c|c|c|c|}
\hline $\begin{array}{l}\text { Name of } \\
\text { the group }\end{array}$ & Sleepir & & $\begin{array}{l}\text { Numbers of tree used for } \\
\text { roosting }\end{array}$ & Plant species used for roosting \\
\hline \multirow{8}{*}{ UMBS } & \multirow{3}{*}{ Summer } & A & 3 & Betula utilis, Quercus incana \\
\hline & & $\mathrm{B}$ & 7 & Betula utilis, Quercus incana \\
\hline & & $\mathrm{C}$ & 5 & Betula utilis, Quercus incana \\
\hline & \multirow{5}{*}{ Winter } & A & 2 & Quercus incana \\
\hline & & $\mathrm{B}$ & 3 & Aesculus indica, Abies pindrow \\
\hline & & $\mathrm{C}$ & 3 & Abies pindrow, Picea smithiana \\
\hline & & $\mathrm{D}$ & 5 & Aesculus indica, Juglans regia, Abies pindrow \\
\hline & & $\mathrm{E}$ & 2 & Juglans regia \\
\hline \multirow{7}{*}{ MMBS } & \multirow{4}{*}{ Summer } & A & 11 & Abies pindrow \\
\hline & & $\mathrm{B}$ & 6 & Quercus incana, Abies pindrow \\
\hline & & $\mathrm{C}$ & 8 & Abies pindrow \\
\hline & & $\mathrm{D}$ & 6 & Aesculus indica, Abies pindrow \\
\hline & \multirow{3}{*}{ Winter } & $\mathrm{A}$ & 7 & Aesculus indica \\
\hline & & B & 4 & Aesculus indica, Abies pindrow \\
\hline & & $\mathrm{C}$ & 6 & Aesculus indica \\
\hline \multirow{9}{*}{ AMB } & \multirow{5}{*}{ Summer } & A & 1 & Abies pindrow \\
\hline & & $\mathrm{B}$ & 2 & Picea smithiana, Abies pindrow \\
\hline & & $\mathrm{C}$ & 2 & Picea smithiana, Abies pindrow \\
\hline & & $\mathrm{D}$ & 2 & Abies pindrow, Pinus wallichiana \\
\hline & & $\mathrm{E}$ & 2 & Pinus wallichiana, Aesculus indica \\
\hline & \multirow{4}{*}{ Winter } & $\mathrm{A}$ & 2 & Aesculus indica, Abies pindrow \\
\hline & & $\mathrm{B}$ & 2 & Cedres deodara \\
\hline & & $\mathrm{C}$ & 2 & Aesculus indica, Cedres deodara \\
\hline & & $\mathrm{D}$ & 2 & Juglans regia \\
\hline
\end{tabular}


during the winter (Tab. 5). The second bisexual focal troop (MMBS) used seven sleeping sites, of those four were used in summer, where they used mostly 6-11 trees of Quercus incana and Abies pindrow while three sites were used in winter on Aesculus indica and Abies pindrow. The langurs of all-male band used 9 roosting sites, of which 5 were used in summer, preferring mostly the Abies pindrow as the roosting tree. During winter, 4 sites were selected, where in Pinus wallichiana, Cedres deodara and Aesculus indica were used for their roosting (Tab. 5).

It was observed that the sleeping sites were usually changed due to the disturbance by the predators and human beings. The langurs of focal troops also shifted their sleeping sites due to the disturbances by the all-male bands.

\subsection{Food and feeding behaviour}

In Machiara National Park, langurs mostly used a combination of fruits, buds, leaves, stems, barks, roots and flowers and were also observed eating insects.

Langurs of study troops were observed consuming plant parts of over 49 species (Tab. 6), found naturally in their habitat except three species (Phaseolus aconitifolius, Solanum tuberosum, Diospyros lotus) which were cultivated by the human beings near the summer residences. During the monsoon months of JulySeptember and also in November they were frequently observed consuming insect larvae. Langurs fed on natural food available in their home ranges the year round. The monthly number of plant species consumed from dawn to dusk fluctuated during the year (Fig. 3).

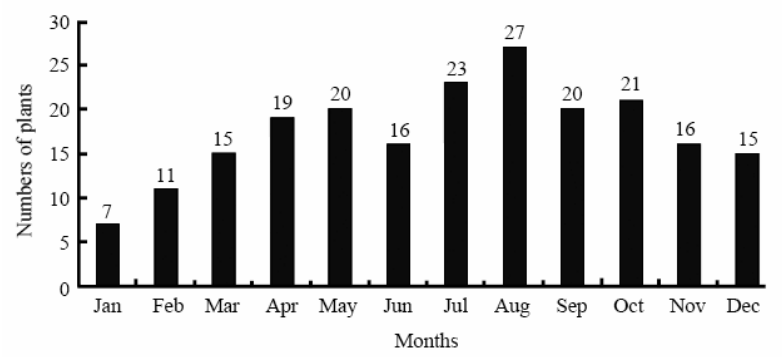

Fig. 3 Number of plant species consumed by langurs in different months of the year 2006 - 2007

The number of plant species and parts consumed varied considerably in different months. In monsoon they consumed a large number of plant species as compared to other months suggesting relationship between the monthly distribution of the number of plant species consumed by langurs and rainfall (Fig. 3).

It shows that during the dry season, the number of species constituting langur food goes down and with the onset of rains the plant texa increase manifolds reaching to a maximum during August (Fig. 3). The plant species consumed by the langurs during summer and winter of $2006-2007$ and average percentages of total feeding time per day (rate of consumption) is given in Tab. 6 .

During summer, 37 plant species were consumed by the langurs of the focal troops. Of these, Betula utilis, Polygonum alpinum, Skimmia laureola, Juniperus communis, Rheum emodi, Ribes alpestre, Quercus incana, Jurinea dolomiaea and Prunus cornuta constitute major share of langur's diet. These species together accounted for about $55 \%$ of total time spent by langurs on feeding. The remaining 29 plant species accounted for about $45 \%$ of feeding time (Fig. 4). Similarly six species Aesculus indica, Quercus incana, Prunus cornuta, Abies pindrow, Vibernum nervosum and Ziziphus jujube constituted more than $70 \%$ of langur's diet during the winter season (Fig. 5). These fifteen plant species accounted for $62.76 \%$ of the total yearly diet of the three focal troops. Among these species, Aesculus indica (14.44\%) followed by Quercus incana (13.83\%), Prunus cornuta (5.66\%) and Betula utilis (5.28 \%) were most commonly used.

Overall, the Aesculus indica was the major part of the langur's diet while the Phaseolus aconitifolius was consumed in least quantity. Many plant species which were infrequently eaten showed strong seasonal variation. About 37 species were consumed during summer, whereas, only 22 species were consumed during cold months from October to March (Fig. 4,5). It showed remarkable seasonal variation not only in their availability but also in their consumption. Aesculus indica $(26.34 \%)$ constituted the major portion of the langur diet during the winter while Betula utilis (10.56\%) was used in summer (Fig. 4, 5). Langurs of troop MMBS were also observed eating insects like termites (Zootermopsis spp), body lice (Pediculus spp) picked up from the bodies of the other individuals during grooming, stick insects and other insect larvae.

The annual distributions of parts of plants utilized by langurs of troop MMBS showed that the langurs spent most of their feeding time on major food types like, mature leaves, young leaves, fruits (generally unripe but occasionally ripe), roots, flowers (both buds and open), stem, bark etc. (Tab. 7). The mature leaves (36.12\%) were preferred to young leaves $(27.27 \%)$. Fruit eating accounted for $17.00 \%$ of the total feeding time. Consumption of roots accounted for about $9.45 \%$, barks for about $6.69 \%$ and remaining items such as flower and 
stem consumption was calculated to be $2.19 \%$ and $1.28 \%$ respectively (Tab. 7).

Tab. 6 Names of the plants consumed and the rate of consumption by the focal troops of the langurs during 2006-2007

\begin{tabular}{|c|c|c|c|c|c|c|c|c|c|}
\hline \multirow[b]{2}{*}{$\begin{array}{c}\text { Sr. } \\
\#\end{array}$} & \multirow[b]{2}{*}{$\begin{array}{l}\text { Name of plant } \\
\text { consumed }\end{array}$} & \multirow[b]{2}{*}{ Local name } & \multirow[b]{2}{*}{ Type } & \multicolumn{3}{|c|}{ Summer } & \multicolumn{3}{|c|}{ Winter } \\
\hline & & & & $\begin{array}{c}\text { Parts } \\
\text { consumed }\end{array}$ & $\begin{array}{l}\text { Average } \\
\text { time (min) } \\
\text { spent in } \\
\text { feeding/ } \\
\text { Day }\end{array}$ & $\begin{array}{c}\text { Rate of } \\
\text { consum- } \\
\text { ption }\end{array}$ & $\begin{array}{c}\text { Parts } \\
\text { consumed }\end{array}$ & $\begin{array}{l}\text { Average } \\
\text { time } \\
\text { (minute) } \\
\text { spent in } \\
\text { feeding/ } \\
\text { day }\end{array}$ & $\begin{array}{c}\text { Rate of } \\
\text { consump- } \\
\text { tion }\end{array}$ \\
\hline 1 & Abies pindrow & Rewar & Tree & Shoots & 6.06 & 1.16 & Shoots, seeds & 17.68 & 4.85 \\
\hline 2 & Pinus wallichiana & Kail & Tree & & & & Shoots, seeds & 13.22 & 3.62 \\
\hline 3 & Taxus wallichiana & Bermi & Tree & Leaves & 5.23 & 1.00 & Shoots & 9.91 & 2.72 \\
\hline 4 & Picea smithiana & Kachhal & Tree & & & & Shoots & 4.56 & 1.25 \\
\hline 5 & Cedrus deodara & Diar & Tree & & & & Seed, shoots & 6.44 & 1.77 \\
\hline 6 & Aesculus indica & Bankhor & Tree & Buds, flowers & 13.26 & 2.54 & $\begin{array}{l}\text { Buds, barks, } \\
\text { fruit }\end{array}$ & 96.07 & 26.34 \\
\hline 7 & Prunus cornuta & Parth & Tree & Buds, fruit & 23.45 & 4.48 & Buds & 24.98 & 6.85 \\
\hline 8 & Quercus incana & Reen & Tree & Buds & 21.36 & 4.09 & Buds, fruit & 85.99 & 23.58 \\
\hline 9 & Grewia tenax & Damanr & Tree & Leaves, fruits & 5.41 & 1.03 & & & \\
\hline 10 & $\begin{array}{l}\text { Parratiopsis } \\
\text { jacquementiana }\end{array}$ & Pashoor & Tree & Buds, shoots & 5.26 & 1.01 & & & \\
\hline 11 & Diospyros lotus & Amlook & Tree & & & & Fruit & 3.25 & 0.89 \\
\hline 12 & Celtis australis & Batkararh & Tree & & & & Fruit & 6.57 & 1.80 \\
\hline 13 & Vibernum nervosum & Guchh & Shrub & Buds, fruit & 17.52 & 3.35 & Buds & 16.05 & 4.40 \\
\hline 14 & Ziziphus jujube & Ber & Shrub & & & & Roots & 15.11 & 4.14 \\
\hline 15 & Ziziphus nummularia & Beri & Shrub & & & & Roots, buds & 13.36 & 3.66 \\
\hline 16 & Rubus spp. & Garachha & Shrub & Leaves & 6.57 & 1.26 & & & \\
\hline 17 & Salix denticulate & Biara & Shrub & Buds & 13.52 & 2.59 & & & \\
\hline 18 & Ribes alpestre & Kag dakh & Shrub & Fruit & 23.67 & 4.53 & & & \\
\hline 19 & Elaeagnus spp. & Kankoli & Shrub & Fruit & 17.56 & 3.36 & & & \\
\hline 20 & Rosa burnonii & $\begin{array}{l}\text { Kuruch/phl } \\
\text { war }\end{array}$ & Shrub & Fruit & 14.05 & 2.69 & & & \\
\hline 21 & Jurinea dolomiaea & & Shrub & Roots & 31.96 & 6.11 & & & \\
\hline 22 & Betula utilis & Burz & Shrub & $\begin{array}{l}\text { Barks, young } \\
\text { Shoots }\end{array}$ & 55.23 & 10.56 & & & \\
\hline 23 & Datura stramonium & Tatura & Shrub & Fruit & 8.54 & 1.63 & & & \\
\hline 24 & Indigofera linifolia & Kainthi & Shrub & Fruit, buds & 6.65 & 1.27 & & & \\
\hline 25 & Vitis vinifera & Dahk & Shrub & Fruits & 4.68 & 0.90 & & & \\
\hline 26 & Ziziphus mauritiana & Sinjli & Shrub & Leaves & 7.6 & 1.45 & Roots buds & 10.56 & 2.90 \\
\hline 27 & Skimmia laureola & Nera & Shrub & Young shoots & 35.63 & 6.81 & & & \\
\hline 28 & Juniperus communis & Metheri & Shrub & Buds & 28.8 & 5.51 & & & \\
\hline 29 & Rosa moschata & Garachha & Shrub & Buds, fruit & 11.97 & 2.29 & & & \\
\hline 30 & Berbris aristidae & Sumbal & Shrub & Flowers, fruit & 5.06 & 0.97 & & & \\
\hline 31 & $\begin{array}{l}\text { Impatiens } \\
\text { edgeworthii }\end{array}$ & Bantil & herb & Fruit & 17.37 & 3.32 & & & \\
\hline 32 & Euphorbia spp. & Hervi & Herb & Leaves, fruits & 9.02 & 1.73 & & & \\
\hline 33 & Solanum nigrum & Kachmach & Herb & Fruits & 7.12 & 1.36 & & & \\
\hline 34 & Dryopteris stewartii & Kunji & Herb & Roots, leaves & 3.58 & 0.68 & Roots & 9.33 & 2.56 \\
\hline 35 & Dryopteris ramose & Nanoor & Herb & $\begin{array}{l}\text { Young shoots, } \\
\text { leaves }\end{array}$ & 5.07 & 0.97 & & & \\
\hline 36 & Lavatera spp. & $\begin{array}{l}\text { Dag } \\
\text { sonchal }\end{array}$ & Herb & Fruits, leaves & 3.11 & 0.59 & & & \\
\hline 37 & Podophyllum emodi & $\begin{array}{l}\text { Ban } \\
\text { khakhri }\end{array}$ & Herb & $\begin{array}{l}\text { Fruits, flowers, } \\
\text { stems }\end{array}$ & 3.0 & 0.57 & & & \\
\hline 38 & Bistorta spp. & Maslonrh & Herb & $\begin{array}{l}\text { Roots, flowers, } \\
\text { roots }\end{array}$ & 11.26 & 2.15 & $\begin{array}{l}\text { Roots, young } \\
\text { leaves }\end{array}$ & 4.99 & 1.37 \\
\hline 39 & Rheum emodi & Gol chitial & Herb & Flowers, stems & 24.46 & 4.68 & $\begin{array}{l}\text { Roots, young } \\
\text { leaves }\end{array}$ & 2.66 & 0.73 \\
\hline
\end{tabular}




\begin{tabular}{|c|c|c|c|c|c|c|c|c|c|}
\hline \multicolumn{10}{|c|}{ (continued) } \\
\hline & & & & & Summer & & & Winter & \\
\hline $\begin{array}{l}\text { Sr. } \\
\#\end{array}$ & $\begin{array}{l}\text { Name of plant } \\
\text { consumed }\end{array}$ & Local name & Type & $\begin{array}{c}\text { Parts } \\
\text { consumed }\end{array}$ & $\begin{array}{c}\text { Average } \\
\text { time (min) } \\
\text { spent in } \\
\text { feeding/ } \\
\text { Day }\end{array}$ & $\begin{array}{c}\text { Rate of } \\
\text { consum- } \\
\text { ption }\end{array}$ & $\begin{array}{c}\text { Parts } \\
\text { consumed }\end{array}$ & $\begin{array}{l}\text { Average } \\
\text { time } \\
\text { (minute) } \\
\text { spent in } \\
\text { feeding/ } \\
\text { day } \\
\end{array}$ & $\begin{array}{c}\text { Rate of } \\
\text { consump- } \\
\text { tion }\end{array}$ \\
\hline 40 & Polygonum alpinum & Chukroon & Herb & Leaves & 41.21 & 7.88 & & & \\
\hline 41 & $\begin{array}{l}\text { Asphodelus } \\
\text { tenuifolius }\end{array}$ & Jangli piaz & Herb & Flowers, leaves & 3.9 & 0.75 & & & \\
\hline 42 & Malva spp. & Sonchal & Herb & Fruit & 3.06 & 0.59 & & & \\
\hline 43 & Cymbopogan martini & Gogoon & Herb & & & & Roots & 12.04 & 3.30 \\
\hline 44 & $\begin{array}{l}\text { Geranium } \\
\text { wallichianum }\end{array}$ & Ratan jog & Herb & & & & Roots & 3.59 & 0.98 \\
\hline 45 & Plantago major & $\begin{array}{l}\text { Chamchi } \\
\text { Patter }\end{array}$ & Herb & Seeds & 4.82 & 0.92 & & & \\
\hline 46 & Fragaria nubicola & Meva & Herb & Fruit & 16.85 & 3.22 & & & \\
\hline 47 & $\begin{array}{l}\text { Phaseolus } \\
\text { aconitifolius }\end{array}$ & Moth & Herb & & & & Fruit & 1.00 & 0.27 \\
\hline 48 & Solanum tuberosum & Aloo & Herb & & & & Stem & 2.04 & 0.56 \\
\hline 49 & Polygonum spp. & Masloonr & Herb & & & & Roots & 5.32 & 1.46 \\
\hline
\end{tabular}
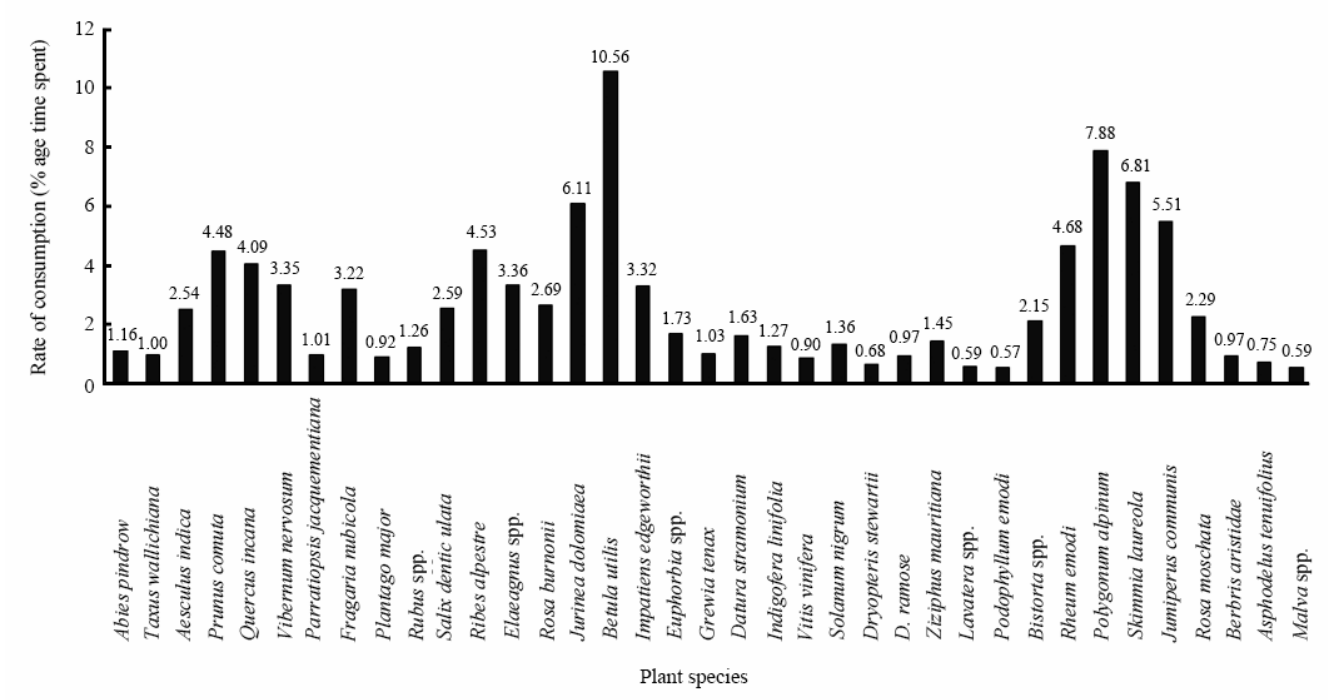

Fig. 4 Rate of consumption (\% age time spent) for different plant species by langurs in MNP during summer 2006 - 2007

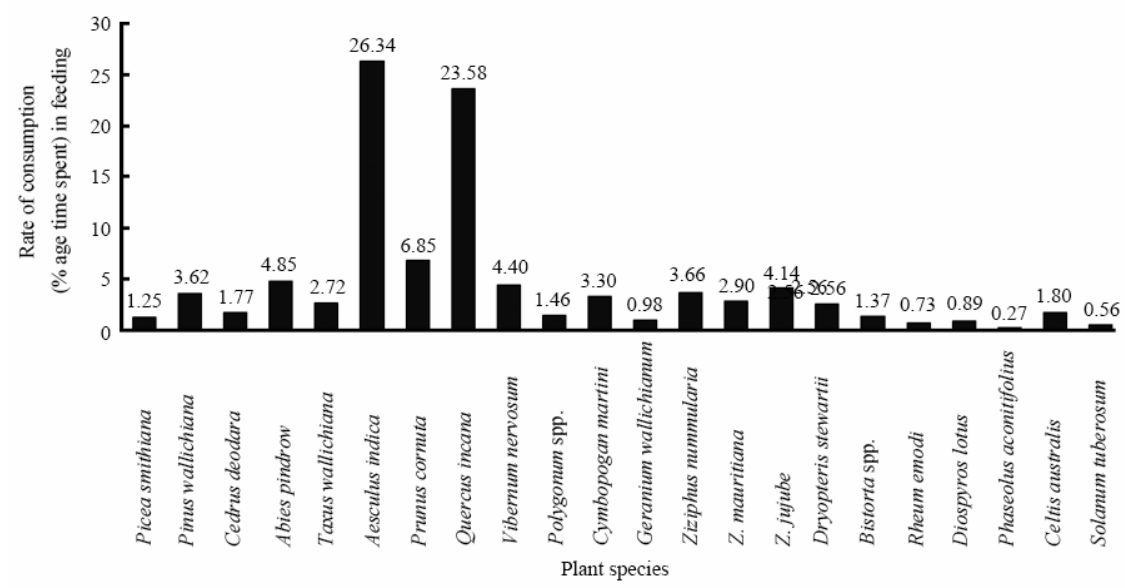

Fig. 5 Rate of consumption (\% age time spent) for different plant species by langurs in MNP during winter 2006 - 2007 


\section{Discussion}

\subsection{Habitat utilization}

The langurs are forest dwelling animals, ecologically adaptable to a variety of habitats, including quite dry savannah as well as tropical rain forests. This is an arboreal and diurnal species. In the study area, they are distributed in moist and dry coniferous forests mixed with deciduous trees and subalpine scrubs between 1700 - 4000 m asl. Nowak (1999), Hilton and Taylor (2000) and Roberts (1997) also reported that the species inhabited between $2200-4000 \mathrm{~m}$ asl in the subtropical, tropical moist temperate, alpine, coniferous, broadleaved forests, including scrublands.

Tab. 7 Percentage time spent in different plant parts used by langurs in MNP during the year 2006 - 2007

\begin{tabular}{lc}
\hline Mature leaves & 36.12 \\
Young leaves, shoots, buds & 27.27 \\
Fruits & 17.00 \\
Flowers & 2.19 \\
Stem & 1.28 \\
Bark & 6.69 \\
Roots & 9.45 \\
\hline
\end{tabular}

\subsection{Food and feeding behaviour}

The contemplation for food and feeding behaviour is essential for the understanding of a species and its ecological adaptation to the environment. Like the other animals the search of food is a crucial part of the langur's lives as they are vital for the maintenance and reproduction of the animals.

Grey Langurs are mainly classified as folivorous species, as they have sacculated stomachs, specialized for the digestion of leaves (Amerasinghe et al, 1971). They have been observed feeding mainly on the leaves and other parts of the plants in the study area. Roberts (1997) stated that langurs are exclusively herbivorous, feeding mainly on young leaf buds, shoots and other vegetations but observations in the open scrub forests of Jodhpur reveal that the insects may also constitute a regular part of their diet and that insectivory is particularly prevalent in the monsoon months of July-September (Srivastava, 1991). Thus, most of the studies suggest that the classification of langurs as folivorous species seems to be a narrow concept because langurs may consume many types of provisioned food in various habitats in India (Rajpurohit, 2005).
Present study showed that about 49 plant species were consumed by the langurs during the study period. In many previous studies at various habitats they are reported to consume 36 - 87 species (Rahman, 1973; Starin, 1973; Yoshiba, 1967; Ripley, 1970; Haldik \& Haldik, 1972; Mohnot, 1974).

It has been observed during the present study that the langurs ingest $36.12 \%$ mature leaves, $27.27 \%$ young leaves, $17.00 \%$ fruits, $2.19 \%$ flowers, $1.28 \%$ stems and $9.45 \%$ bark of the plants. Rajpurohit (2005) observed during one year an average of $6 \%$ leaves, $23 \%$ fruits and $7 \%$ flowers. Among the leaves, about two thirds $(38.5 \%)$ of total feeding time were devoted to mature leaves and about $27.5 \%$ on young leaves. Similarly, the average yearly diet of langurs reported by Rahman (1973) consisted of $85.4 \%$ leaves. Yoshiba (1967) observed that langurs spent $94.6 \%$ of their feeding time on leaves, $1.7 \%$ on fruits and $1.2 \%$ on flowers. In other studies by Ripley (1970), Haldik and Haldik (1972), the langurs consumed about $71.9 \%-83.7 \%$ of leaves, $7.9 \%$ $-12.5 \%$ of fruits and $7.9 \%-6.8 \%$ of flowers. Stanford (1991) reported that Capped langurs (Presbytis pileata) in Madhupur National Park in north-central Bangladesh also consumed $42 \%$ mature leaves of their annual diet. Thus from the above studies it can be concluded that the langurs almost consumed more leaves (about $85 \%$ ) and are exclusively herbivorous. This large amount of leaves consumed by the langurs is due to several physiological and behavioural adaptations. This helps them to survive on their relatively un-nutritional diet through most of the day and gain energy by steady foraging for long periods of time that involves little movement (Rajpurohit, 2005). Similarly flowers are particularly important source of food during flowering seasons which may also aid animals through a vulnerable stage of life (Daubenmire, 1971).

During the present study langurs were observed consuming insects in several episodes. Moore (1985) has also reported that langurs preyed and consumed insect pupae and eggs of birds during several observations. He concluded that the insect-eating by langurs was best explained by an energy/nutrient maximization model, rather than as a consequence of any special characteristic of meat itself. Insectivory in langurs is also reported by Srivastava (1991) and Rajpurohit (2005) in the Jodhpur langur population.

\section{Conclusions}

In Machiara National Park, langurs mostly inhabit 
in the moist temperate coniferous forests mixed with deciduous trees. The langurs are folivorous animals and during the study they were observed consuming more than 49 plant species. Of those Betula utilis, Polygonum alpinum, Skimmia laureola, Juniperus communis, Rheum emodi, Ribes alpestre, Quercus incana, Jurinea dolomiaea and Prunus cornuta constitute the major share

\section{References:}

Ahmed KB, Awan MS, Anwar M. 1999. Status of major wildlife species in Moji Game Reserve, Leepa Valley Azad Kashmir [J]. Proc Pak Congr Zool, 19: 173-182.

Altman J. 1974. Observational study of behaviour: Sampling methods [J]. Behaviour, 49: 227-267.

Amerasinghe FP, Cuylenberg BWB, Haldik CM. 1971. Comparative histology of the alimentary tract of Ceylon primates in correlation with the diet [J]. Ceylon J Sci Biol Sci, 9: 75-87.

Bagchi S, Goyal SP, Sankar K. 2003. Prey abundance and prey selection by tigers (Panthera tigris) in a semi-arid, dry deciduous forest in western India [J]. J Zool, 260(3): 285-290.

Baig KJ. 2004. Progress Report, Compilation of Baseline Data for Zoological and Wildlife Studies in Machiara National Park [M]. Kashmir:Department of Wildlife and Fisheries, Government of Azad Jammu and Kashmir,1-78.

Biswas S, Sankar K. 2002. Prey abundance and food habit of tigers (Panthera tigris tigris) in Pench National Park, Madhya Pradesh, India [J]. J Zool, 256(3): 411-420.

Chhangai AK, Mohnot SM. 2004. Crop Raid by Hanuman Langur Semnopithecus entellus in and around Aravallis, (India) and its Management [J]. Primate Report, 69: 35-47.

Dar NA. 2006. Wildlife of Azad Kashmir (in Urdu) [M]. Muzaffarabad AJK: Al-Sheikh Press, 1-69.

Daubenmire R. 1971. Phenology and other characteristics of tropical emideciduous forest in North-Western Costa Rica [J]. J Ecol, 60: 147-170.

Haldik CM, Haldik A. 1972. Disponibilities allimentariret domains vitaux des primates a Ceylon [J]. Terre Vie, 26: 149-215.

Hassan SA. 2004. Final Report, Compilation of a Baseline Data for Ornithological Studies in Machiara National Park [M]. Department of Wildlife and Fisheries, Government of Azad Jammu and Kashmir,104.

Hilton-Taylor C. (compiler). 2000. 2000 IUCN Red List of Threatened Species [C]. Gland, Switzerland and Cambridge, UK: IUCN,

IUCN. 2006. IUCN Red List of Threatened Species[EB/OL]. $<$ http://www.iucnredlist.org/>.

Mohnot SM. 1974. Ecology and Behaviour of the Common Indian Langur, Presbytis entellus [D]. Ph.D. thesis, Univ. of Jodhpur, Jodhpur India.

Moore J. 1985. Insectivory by grey langurs [J]. J Bombay Nat Hist Soc, of langur's diet in summer while Aesculus indica, Quercus incana, Prunus cornuta, Abies pindrow, Vibernum nervosum and Ziziphus jujube during winter. In Machiara National Park, langurs preferred mature leaves as compared to the other parts of the plants and the availability of the food plant is sufficient for the existing langur population in the area.

82(1): $38-44$

Nandi JS, Tikute SA, Chhangani AK, Potdar VA, Tiwari-Mishra M, Ashtekar RA, Kumari J, Walimbe A, Mohnot SM. 2003. Natural infection by simian retrovirus-6 (SRV-6) in Hanuman langurs (Semnopithecus entellus) from two different geographical regions of India [J]. Virology, 311(1): 192-201.

Nowak RM. 1999. Walker's Mammals of the World [M]. Baltimore: The Johns Hopkins Press.

Preston-Mafham, Rod, Ken. 1992. Primates of the World[M]. London: Blandford Publishing.

Rahman H. 1973. The langurs of Gir Sanctuary (Gujarat). A preliminary survey [J]. J Bomb Nat Hist Soc, 70: 194-314.

Rajpurohit DS. 2005. Study the Dominance Hierarchy and its Role in Social Organization in Hanuman langur, Semnopithecus entellus entellus [D]. Ph.D. thesis, Jai Narain Vyas University, Jodhpur (Rajasthan) India.

Ripley S. 1970. Leaves and leaf monkeys: the social organization of foraging in gray langurs, Presbytis entellus thersites [M]// Napier JR, Napier PH. Old World Monkeys: Evolution, Systematics and Behaviour. London: Academic Press, 481-509.

Roberts TJ. 1997. The Mammals of Pakistan[M]. Revised ed. Karachi: Oxford University Press, 1-525.

Roonwal ML, Mohnot SM. 1977. Primates of South Asia [M]. Cambridge: Harvard University Press.

Srivastava A. 1991. Insectivory and its significance to langur diets [J]. Primates, 32(2): 237-241.

Stanford CB. 1991. The diet of the capped langur (Presbytis pileata) in a moist deciduous forest in Bangladesh [J]. Int J Primatol, 12(3): 199-216.

Starin ED. 1973. A Preliminary Study of the Gir Forest Langur [D]. BA thesis, Friends World College, Huntinglon, New York.

Thorington RWJ, Anderson S. 1984. Orders and Families of Recent Mammals of the World [M]. NY: John Wiley and Sons, xii+686.

Tritsch MF. 2001. Wildlife of India [M]. India: Thomson Press Ltd.

Walker S, Molur S. (Compilers). 2004. Summary of the Status of South Asian Primates [R]// Exteracted from the CAMP 2003 Report., $2^{\text {nd }}$ ed. Coimbatore, India: Zoo Outreach Organization, CBSG-South Asia and WILD.

Yoshiba K. 1967. An ecological study of Hanuman langur, Presbytis entellus [J]. Primates, 8: 127-154. 